\title{
Pengaruh Kompensasi dan Motivasi terhadap Kinerja Karyawan (Studi Kasus pada Karyawan
} PT Dipa Pharmalab Internsains Jakarta)

\author{
Fransisca Marseilla ${ }^{1}$ \\ ${ }^{1}$ PT. Energi Unggul Persada (KPN Corp) Jakarta \\ fmseilla@gmail.com
}

DOI: https://doi.org/10.24071/exero.v3i2.4301

\begin{abstract}
Abstrak
Penelitian ini bertujuan untuk mengetahui pengaruh kompensasi dan motivasi terhadap kinerja karyawan PT DIPA Pharmalab Intersains Jakarta. Populasi dalam penelitian ini adalah karyawan PT DIPA Pharmalab Intersains Jakarta, dengan sampel sebanyak 100 responden. Pengambilan sampel menggunakan teknik Proportional Random Sampling. Teknik pengumpulan data yang digunakan adalah wawancara dan kuesioner. Data dianalisis dengan analisis regresi linier berganda, uji $F$, uji $t$, dan koefisien Determinasi. Hasil penelitian ini menunjukkan bahwa kompensasi dan motivasi berpengaruh secara bersama-sama terhadap kinerja karyawan, secara parsial motivasi berpengaruh terhadap kinerja karyawan, dan kompensasi tidak berpengaruh terhadap kinerja karyawan.
\end{abstract}

Kata kunci: kompensasi, motivasi, kinerja karyawan

\begin{abstract}
The aim of this research is to find out the influence of compensation and motivation on work performance of the employees of PT DIPA Pharmalab Intersains Jakarta. The population of this research is the employees of PT DIPA Pharmalab Intersains Jakarta and the sample consists of 100 respondents. The sampling technique used in this research is purposive sampling. The data collection technique includes interview and self-report questionnaire. The data is analyzed by using statistical techniques including multiple linear regression, F-test, T-test and determinant coefficient. The result of the analysis suggests that simultaneously compensation and motivation influence the employees' work performance. Partially, motivation influences the employees' work performance, and whereas compensation does not.
\end{abstract}

Keywords: compensation, motivation, employee performance

\section{Pendahuluan}

Suatu perusahaan umumnya mengharapkan usahanya mencapai kemajuan dan perkembangan. Capaian kemajuan dan perkembangan itu tidak lepas dari peran sumber daya manusia di organisasi. Hariandja (2002: 3) menyatakan bahwa sumber daya manusia merupakan salah satu faktor yang sangat penting dalam suatu perusahaan disamping faktor yang lain seperti modal. Oleh karena itu, sumber daya manusia harus dikelola dengan baik untuk meningkatkan efektivitas dan efisiensi organisasi.

Dalam mencapai tujuan suatu perusahaan diperlukan sumber daya manusia yang kompeten dan memiliki kinerja yang baik sehingga dapat menunjang keberhasilan bisnis. Seperti yang dipaparkan oleh Samsudin (2010:30), tujuan sumber daya manusia adalah memperbaiki kontribusi produktif tenaga kerja terhadap organisasi dengan cara yang bertanggung jawab secara strategis, etis, dan sosial. 
Pada suatu perusahaan, sumber daya manusia membutuhkan dorongan dan semangat agar bekerja lebih maksimal. Widodo (2015:187), menyatakan bahwa motivasi adalah suatu kekuatan yang menyebabkan seseorang menghasilkan sesuatu sesuai dengan apa yang ia katakan, bukan sekedar janji dan keinginan saja. Motivasi yang rendah dapat membuat individu yang berkualitas tinggi mempunyai kinerja yang buruk. Sebaliknya dengan pemberian motivasi secara berkala yang layak dapat membuat individu yang berkualitas rendah mempunyai kinerja yang baik.

Selain motivasi, kinerja karyawan juga dipengaruhi oleh kompensasi. Kompensasi dapat meningkatkan produktivitas kerja para karyawan, kompensasi yang adil akan menghasilkan dampak positif dalam efisiensi kerja di suatu organisasi bagi setiap karyawannya. Jika kompensasi yang diterima karyawan sesuai atau bahkan melebihi apa yang dipersepsikannya maka akan menimbulkan rasa puas pada diri karyawan, sehingga karyawan akan meningkatkan kinerja yang telah dicapainya saat ini (Sunyoto, 2012). Sebaliknya kompensasi yang tidak dikelola dengan baik akan menyebabkan karyawan tidak puas sehingga karyawan dapat mengekspresikan diri mereka dalam bentuk penurunan kinerja, protes keras, mogok kerja serta sangat mungkin karyawan akan meninggalkan perusahaan (Moeheriono, 2012). Dengan demikian, dapat dilihat bahwa motivasi dan kompensasi mempengaruhi kinerja karyawan.

Pemberian kompensasi dapat menjadi masalah jika perusahaan melakukan ketidakadilan kepada karyawannya. Misalnya perusahaan memberi gaji, insentif, dan penghargaan yang tidak sesuai dengan perjanjian yang telah disepakati oleh karyawan dan perusahaan sehingga karyawan memutuskan keluar dan pindah ke perusahaan lain atau mendirikan usaha sendiri. Kompensasi menjadi salah faktor satu pendukung dalam meningkatkan kinerja bagi seorang karyawan dalam menyelesaikan suatu kewajiban. Motivasi tentu perlu dimiliki oleh seorang karyawan agar pekerjaan yang dilakukan memberikan hasil yang dapat mendukung pencapaian visi misi perusahaan.

Kinerja suatu perusahaan merupakan jawaban dari berhasil atau tidaknya perencanaan tujuan perusahaan yang telah ditetapkan. Siswanto (2010) menjelaskan bahwa kinerja karyawan adalah hasil akhir penilaian atau hasil kerja yang dicapai dari sebuah pelaksanaan tugas dan tanggung jawab yang menggambarkan seberapa 
baik karyawan dalam melaksanakan pekerjaannya. Hasil atau prestasi kerja yang baik akan berdampak pada pencapaian tujuan organisasi. Karyawan yang mempunyai keinginan atau motivasi tertentu akan dapat mendorong dirinya untuk mencapai kinerja yang diharapkan oleh perusahaan. Pada suatu perusahaan baik sektor publik ataupun swasta, kinerja menjadi sorotan terkait dengan kualitas pelayanan yang diberikan. Tentu untuk meningkatkan kinerja, perusahaan dapat memberikan motivasi bagi karyawan. Motivasi dapat diberikan dengan cara memberikan penghargaan atau balas jasa.

Penelitian ini dilakukan dengan tujuan untuk mengetahui pengaruh kompensasi dan motivasi secara parsial dan bersama-sama terhadap kinerja karyawan PT DIPA Pharmalab Intersains Jakarta. Perusahaan ini merupakan importir, pemasar dan distributor untuk peralatan medis dan obat-obatan di Indonesia. Perusahaan didirikan tahun 1991 dan saat ini telah memiliki 45 cabang di seluruh Indonesia. Pendapatan tahun 2006 kurang lebih USD 17,1 juta dengan pertumbuhan hampir $50 \%$.

\section{Kajian Literatur}

\section{Kompensasi}

Rivai dan Sagala (2011:741) menyatakan bahwa kompensasi adalah persepsi karyawan atas besarnya balas jasa yang diterima dari perusahaan, dengan dimensi gaji, insentif, tunjangan, penghargaan prestasi, dan fasilitas. Pemberian kompensasi yang layak bukan saja dapat mempengaruhi kondisi materi para karyawan, tetapi juga dapat menentramkan batin karyawan untuk bekerja lebih tekun dan mempunyai inisiatif (Sutrisno, 2011).

Menurut Ardana, Muljati, dan Mudiartha (2012:154) fungsi dan tujuan pemberian kompensasi adalah:

a. Menjalin ikatan kerja sama formal antara atasan dengan karyawan, dimana karyawan harus mengerjakan tugas-tugas dengan baik, sedangkan pengusaha atau majikan wajib membayar kompensasi itu sesuai dengan perjanjian.

b. Kepuasan kerja yaitu karyawan dapat memenuhi kebutuhan fisik, sosial, egoistiknya sehingga karyawan memperoleh kepuasan kerja dari jabatan itu.

c. Motivasi, yaitu jika balas jasa yang diberikan cukup besar, manajer akan lebih mudah memotivasi bawahannya. 
d. Stabilitas karyawan, yaitu dengan program kompensasi atas prinsip adil dan layak serta eksternal konsistensi yang kompetitif maka stabilitas karyawan akan lebih terjamin karena turnover relatif kecil.

e. Disiplin, yaitu dengan pemberian balas jasa yang cukup, maka disiplin karyawan akan semakin baik, mereka akan menyadari dan mentaati peraturan yang berlaku.

f. Pengaruh serikat pekerja yaitu dengan program kompensasi yang baik, pengaruh serikat pekerja dapat dihindari dan karyawan akan berkonsentrasi pada pekerjaan.

g. Pengaruh pemerintah, yaitu jika program kompensasi tersebut sesuai dengan undang-undang ketenagakerjaan yang berlaku (seperti balas upah minimum), maka intervensi pemerintah dapat dihindarkan.

Menurut Sofyandi (2008) kompensasi terdiri dari dua macam, yaitu kompensasi langsung (direct compensation) dan kompensasi tidak langsung (indirect compensation). Kompensasi langsung adalah suatu balas jasa yang diberikan kepada karyawan karena telah memberikan prestasinya demi kepentingan perusahaan. Kompensasi ini diberikan karena berkaitan secara langsung dengan pekerjaan yang dilakukan oleh karyawan tersebut. Contoh kompensasi langsung : gaji atau upah, insentif atau bonus. Kompensasi tidak langsung adalah pemberian kompensasi kepada karyawan sebagai tambahan yang didasarkan kepada kebijakan pemimpin dalam rangka upaya meningkatkan kesejahteraan karyawan. Tentunya pemberian kompensasi ini tidak secara langsung berkaitan dengan pekerjaan yang dilakukan oleh karyawan tersebut. Contoh kompensasi tidak langsung : tunjangan hari raya, tunjangan pensiun, termasuk fasilitas-fasilitas dan pelayanan yang diberikan perusahaan.

\section{Motivasi}

Motivasi adalah serangkaian kekuatan yang menyebabkan orang-orang berperilaku dengan cara tertentu (Moorhead dan Griffin, 2013 : 86). Sedangkan menurut Widodo (2015:187), motivasi adalah suatu kekuatan yang menyebabkan seseorang menghasilkan sesuatu sesuai dengan apa yang ia katakan, bukan sekedar janji dan keinginan saja. 
Herzberg mengemukakan teori motivasi berdasar teori dua faktor yaitu faktor hygiene dan motivator (Moorhead dan Griffin, 2013: 94). Herzberg menyatakan bahwa orang dalam melaksanakan pekerjaannya dipengaruhi oleh dua faktor yang merupakan kebutuhan, yaitu:

a. Faktor maintenance, yaitu berhubungan dengan hakikat manusia yang ingin memperoleh ketentraman badaniah. Kebutuhan kesehatan ini merupakan kebutuhan yang berlangsung terus-menerus, karena kebutuhan ini akan kembali pada titik nol setelah dipenuhi.

b. Faktor motivasi, yaitu menyangkut kebutuhan psikologis seseorang seperti perasaan sempurna dalam melakukan pekerjaan. Faktor ini berhubungan dengan penghargaan terhadap pribadi yang berkaitan langsung dengan pekerjaan.

Teori Herzberg ini melihat ada dua faktor yang mendorong karyawan termotivasi, faktor intrinsik yaitu daya dorong yang timbul dari dalam diri masingmasing orang dan faktor ekstrinsik yaitu daya dorong yang datang dari luar diri seseorang, terutama dari organisasi tempatnya bekerja, dengan dimensi prestasi, tanggung jawab, pengembangan karir, pengakuan orang lain, dan pekerjaan itu sendiri.

Menurut Hasibuan (2009) terdapat tujuan beberapa pemberian motivasi kepada pegawai, yaitu :

a. Meningkatkan moral dan kepuasan kerja.

b. Meningatkan produktivitas kerja karyawan.

c. Mempertahankan kestabilan karyawan perusahaan.

d. Meningkatkan kedisiplinan karyawan.

e. Mengefektifkan pengadaan karyawan.

f. Menciptakan suasana dan hubungan kerja yang baik.

g. Meningkatkan loyalitas, kreativitias dan partisipasi karyawan.

h. Meningkatkan tingkat kesejahteraan karyawan.

i. Mempertinggi rasa tanggung jawab terhadap tugas karyawan.

j. Meningkatkan efisiensi penggunaan alat-alat dan bahan baku.। 


\section{Kinerja Karyawan}

Cormick dan Tiffin dikutip dalam Sutrisno (2010:172) menyampaikan bahwa kinerja adalah kuantitas, kualitas dan waktu yang digunakan dalam menjalankan tugas. Selain itu, Moeheriono (2012), mendefinisikan kinerja atau performance sebagai hasil kerja yang dapat dicapai oleh seseorang atau sekelompok orang dalam suatu organisasi baik secara kuantitatif maupun kualitatif, sesuai dengan kewenangan dan tugas tanggung jawab masing-masing dalam upaya mencapai tujuan organisasi bersangkutan secara legal, tidak melanggar hukum dan sesuai dengan moral maupun etika.

Menurut Widodo ( 2015:138), tujuan dari penilaian kinerja, yaitu:

a. Untuk mengetahui keterampilan dan kemampuan karyawan.

b. Sebagian besar di bidang kepegawaian, khususnya penyempurnaan kondisi kerja, peningkatan mutu dan hasil kerja.

c. Mendorong terciptanya hubungan timbal balik yang sehat antara atasan dan bawahan.

d. Mengetahui kondisi organisasi secara keseluruhan dari bidang kepegawaian khususnya karyawan dalam bekerja.

e. Secara pribadi, karyawan mengetahui kekuatan dan kelemahannya sehingga dapat memacu perkembangannya. Bagi atasan yang menilai akan lebih memperhatikan dan mengenal bawahan dan pegawainya, sehingga dapat lebih memotivasi pegawai.

Menurut Widodo (2015:133), kinerja dipengaruhi, oleh:

a. Kualitas dan Kemampuan Karyawan, yaitu hal-hal yang berhubungan dengan pendidikan/pelatihan, etos kerja, motivasi kerja, sikap mental dan kondisi fisik karyawan.

b. Sarana Pendukung, yaitu berhubungan dengan lingkungan kerja (keselamatan kerja, kesehatan kerja, sarana produksi, teknologi) dan hal-hal yang berhubungan dengan kesejahteraan karyawan (upah atau gaji, jaminan sosial, keamanan kerja).

c. Supra Sarana, meliputi suatu hal yang berhubungan dengan kebijaksanaan pemerintah dan hubungan industrial 


\section{Penelitian Sebelumnya}

1. Sugiannor (2014) meneliti "Pengaruh Kompensasi dan Motivasi Kerja terhadap Kinerja Karyawan bagian pemasaran di PT Coca Cola Distribution Indonesia Sales Office Banjarbaru" dengan sampel sebanyak 44 orang karyawan. Hasil penelitian ini menunjukkan bahwa variabel kompensasi (X1) dan variabel motivasi kerja (X2) secara parsial berpengaruh terhadap kinerja dan semua variabel bebas memiliki pengaruh signifikan terhadap variabel terikat secara simultan. Variabel kompensasi (X1) merupakan variabel yang paling dominan mempengaruhi kinerja.

2. Tanto Wijaya dan Fransisca Andreani (2015) meneliti "Pengaruh Motivasi dan Kompensasi terhadap Kinerja Karyawan” pada PT Sinar Jaya Abadi Bersama. Populasi berjumlah 39 karyawan dengan teknik pengmbilan sampel sensus dan menjadikan anggota populasi sebagai sampel. Hasil dari penelitian ini didapatkan bahwa motivasi dan kompensasi berpengaruh secara simultan terhadap kinerja karyawan. Dari hasil uji t motivasi berpengaruh positif dan signifikan terhadap kinerja karyawan, kompensasi berpengaruh positif dan signifikan terhadap kinerja karyawan.

3. Yulia Suwati (2013) meneliti Pengaruh Kompensasi dan Motivasi Kerja terhadap Kinerja Karyawan pada PT Tunas Hijau Samarinda. Populasi berjumlah 130 karyawan dengan sampel yang diambil sebanyak 57 karyawan. Hasil uji simultan menunjukkan bahwa motivasi dan kompensasi secara bersama-sama mempunyai pengaruh yang signifikasi terhadap kinerja karyawan. Motivasi kerja secara parsial tidak berpengaruh positif dan signifikan terhadap kinerja karyawan sedangkan kompensasi secara parsial berpengaruh positif dan signifikan terhadap kinerja karyawan.

4. Utami, Rodhiyah, dan Nurseto (2015) meneliti "Pengaruh Lingkungan Kerja dan Kompensasi terhadap Kinerja Karyawan" pada CV Cynthia Box di Kudus. Penelitian ini menggunakan pendekatan explanatory research dengan sampel sebanyak 45 karyawan dari bagian produksi. Hasil penelitian secara parsial menemukan bahwa kompensasi tidak berpengaruh terhadap kinerja karyawan, sedangkan secara simultan lingkungan kerja 
dan kompensasi secara bersama-sama berpengaruh positif dan signifikan terhadap kinerja karyawan.

Adapun kerangka pemikiran dalam penelitian ini dapat digambarkan sebagai berikut:

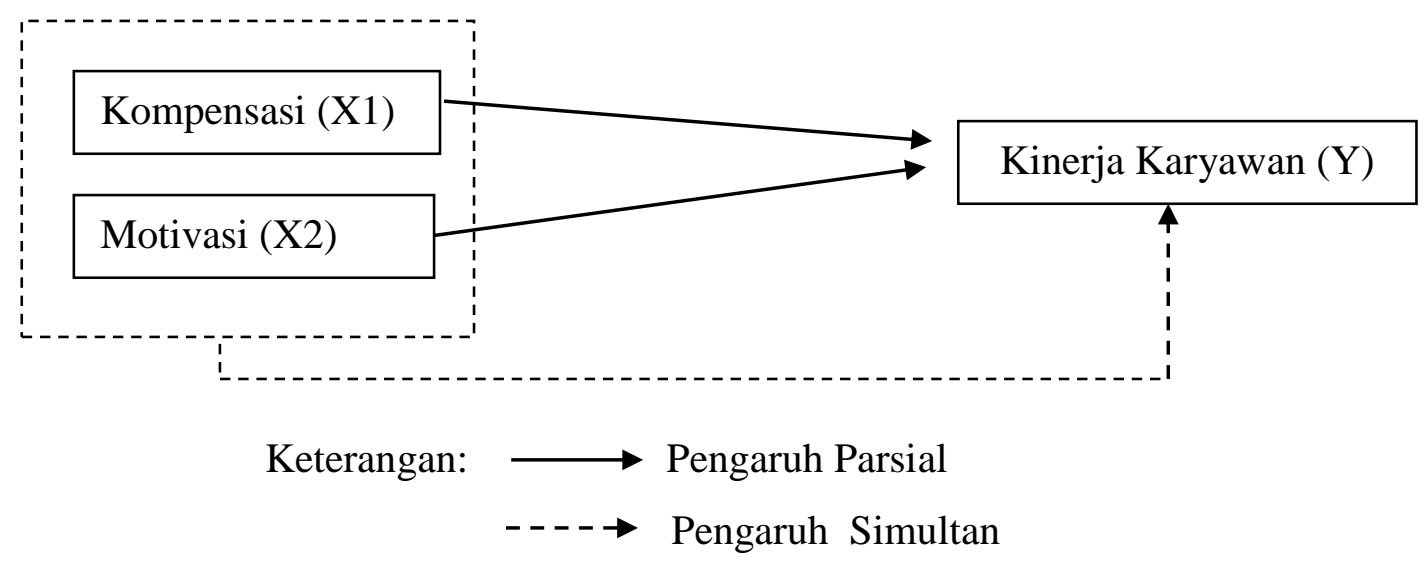

Gambar 1. Kerangka Konseptual

\section{Rumusan Hipotesis}

\section{Pengaruh kompensasi terhadap kinerja karyawan PT DIPA Pharmalab Intersains Jakarta}

Rivai dan Sagala (2011:741), menyatakan bahwa kompensasi adalah persepsi karyawan atas besarnya balas jasa yang diterima dari perusahaan. Besarnya kompensasi yang diterima seorang karyawan sering berkaitan dengan jabatan maupun tanggung jawab di suatu organisasi. Semakin tinggi jabatan seseorang maka tanggung jawabnya semakin besar sehingga kompensasi yang diterima semakin tinggi. Jika kompensasi yang diterima layak dan sebanding dengan tanggung jawab yang dimiliki, maka kompensasi dapat meningkatkan kinerja karyawan. Sebaliknya pemberian kompensasi yang kurang layak dan tidak sesuai dengan tanggung jawab yang diberikan dapat berpengaruh pada menurunnya kinerja karyawan. Wijaya dan Andreani (2015) dan Suwati (2013) menemukan bahwa kompensasi berpengaruh terhadap kinerja karyawan. Oleh karena itu, hipotesis yang dirumuskan adalah :

H1 : Kompensasi berpengaruh positif terhadap kinerja karyawan PT DIPA Pharmalab Intersains Jakarta. 


\section{Pengaruh Motivasi Terhadap Kinerja Karyawan PT DIPA Pharmalab Intersains Jakarta}

Motivasi adalah serangkaian kekuatan yang membuat orang bersedia terlibat dalam suatu perilaku (Moorhead dan Griifin, 2013 : 86). Seorang pimpinan seharusnya dapat memberikan motivasi kepada karyawan tanpa memandang jabatan tertentu. Semakin banyak motivasi yang diterima oleh karyawan atau semakin tinggi motivasi yang dimiliki karyawan maka akan dapat meningkat kinerja karyawan. Sebaliknya jika seorang karyawan yang tidak memiliki motivasi atau motivasinya rendah maka akan menjadi kurang produktif. Arzani et al. (2018), Wijaya dan Andreani (2015) menemukan bahwa motivasi berpengaruh terhadap kinerja karyawan. Oleh karena itu, hipotesis yang dirumuskan adalah

H2 : Motivasi berpengaruh positif terhadap kinerja karyawan PT DIPA Pharmalab Intersains Jakarta.

\section{Pengaruh Kompensasi Dan Motivasi Terhadap Kinerja Karyawan PT DIPA Pharmalab Intersains Jakarta}

Kinerja karyawan adalah kuantitas, kualitas dan waktu yang digunakan dalam menjalankan tugas (Cormick dan Tiffin) dikutip dalam Sutrisno (2010: 172). Kinerja karyawan dapat dipengaruhi oleh kompensasi dan motivasi. Pemberian kompensasi dan motivasi yang seimbang akan dapat meningkatkan kinerja karyawan. Dalam hal ini, seorang karyawan akan menjadi lebih bersemangat untuk menyelesaikan tugas sesuai tanggung jawab yang diberikan dengan baik. Sugiannor (2014) dan Wijaya \& Andreani (2015) menemukan bahwa kompensasi dan motivasi secara bersama-sama berpengaruh terhadap kinerja. Oleh karena itu, hipotesis yang dirumuskan adalah H3 : Kompensasi dan motivasi berpengaruh secara bersama-sama terhadap kinerja karyawan PT DIPA Pharmalab Intersains

\section{Metode Penelitian}

Jenis penelitian ini adalah observasi. Observasi merupakan sebuah metode yang akurat dan spesifik dalam melakukan pengumpulan data serta memiliki tujuan 
mencari informasi mengenai segala kegiatan yang sedang berlangsung untuk dijadikan objek kajian dalam sebuah penelitian (Patton, 2009).

Penelitian ini dilakukan di PT Dipa Pharmalab Intersains Jakarta pada bulan Juli 2018. Populasi dalam penelitian ini adalah seluruh karyawan dari semua divisi PT Dipa Pharmalab Intersains Jakarta yang berjumlah 696 orang. Sampel penelitian sebanyak 100 orang karyawan terdiri dari 87 orang di kantor pusat dan 13 orang di kantor cabang. Pengambilan sampel menggunakan teknik purposive sampling. Adapun kriteria untuk menjadi responden penelitian ini adalah karyawan PT Dipa Pharmalab Intersains Jakarta yang sudah bekerja lebih dari 1 tahun dan yang sudah diangkat sebagai pegawai tetap.

Data penelitian ini terdiri dari data primer dan data sekunder. Data primer didapatkan melalui wawancara dan menyebarkan kuesioner kepada para karyawan. Data sekunder digunakan untuk mengetahui sejarah perusahaan, produk-produk perusahaan, dan kantor pusat serta cabang perusahaan

Variabel penelitian ini terdiri dari kompensasi, motivasi sebagai variabel bebas dan kinerja karyawan sebagai variabel terikat. Rivai dan Sagala (2011 :741) menyatakan bahwa kompensasi adalah persepsi karyawan atas besarnya balas jasa yang diterima dari perusahaan. Kompensasi memiliki tiga (3) indikator yaitu 1) Puas terhadap kesesuaian gaji dan pekerjaan yang diterima, 2) Puas terhadap penghargaan, pujian, dan peluang promosi, 3) Puas terhadap fasilitas yang diberikan dalam menunjang pekerjaan. Motivasi merupakan daya dorong yang datang dari luar diri seseorang, terutama dari organisasi tempatnya bekerja (Herzberg dalam Hasibuan, 1990: 177). Motivasi memiliki lima (5) indikator yaitu 1) Pekerjaan yang memberikan prestasi kepada karyawan, 2) Menyelesaikan pekerjaan sesuai dengan ketentuan perusahaan, 3) Kesempatan jenjang karir, promosi, serta pelatihan, 4) Penghargaan dan pujian terhadap kemampuan karyawan menyelesai kan pekerjaan, dan 5) Pekerjaan yang tidak rutin, menarik, serta menantang dan membutuh kan inovasi. Kinerja adalah kuantitas, kualitas dan waktu yang digunakan dalam menjalankan tugas (Cormick dan Tiffin dikutip dalam Sutrisno, 2010: 172). Kinerja memiliki tiga (3) indikator yaitu 1) Penyelesaian hasil pekerjaan yang sesuai dengan standar kualitas perusahaan, 2) Jumlah dari hasil pekerjaan yang sudah diselesaikan, dan 3) Pemanfaatan waktu dalam penyelesaian pekerjaan. 
Variabel diukur dengan skala Likert 1-5 yaitu Sangat Tidak Setuju (1), Tidak Setuju (2), Kurang Setuju (3), Setuju (4), dan Sangat Setuju (5). Teknik pengujian instumen memakai uji validitas dan reliabilitas. Analisis regresi linier berganda digunakan untuk mengetahui ada tidaknya pengaruh variabel bebas terhadap variabel terikat. Adapun persamaan regresi linier berganda yang digunakan adalah :

$$
\mathrm{KK}=\mathrm{a}+\mathrm{b}_{1} \mathrm{~K}_{1}+\mathrm{b}_{2} \mathrm{M}_{2}+\mathrm{e}
$$

Keterangan :

$$
\begin{array}{ll}
\mathrm{KK} & =\text { kinerja karyawan } \\
\mathrm{a} & =\text { konstanta } \\
\mathrm{b}_{1} & =\text { koefisien regresi kompensasi } \\
\mathrm{b}_{2} & =\text { koefisien regresi motivasi } \\
\mathrm{K}_{1} & =\text { kompensasi } \\
\mathrm{M}_{2} & =\text { motivasi } \\
\mathrm{e} & =\text { error }
\end{array}
$$

\section{Hasil dan Pembahasan}

\section{Karateristik Responden}

Responden penelitian ini berjumlah 100 orang yang terdiri dari 47 orang (47\%) laki-laki dan 53 orang (53\%) perempuan, 56 orang (56\%) menikah dan 44 orang (44\%) belum menikah. Responden berusia 20 - 24 tahun sebanyak 19 orang (19\%), 25 - 34 tahun sebanyak 57 orang (57\%), 35 - 44 tahun sebanyak 20 orang (20\%), dan di atas 45 tahun sebanyak 4 orang (4\%). Mayoritas responden (54\%) memiliki pendidikan terakhir S1, sisanya $23 \%$ memiliki pendidikan terakhir SMA/SMK, $19 \%$ memiliki pendidikan terakhir D3, dan $4 \%$ memiliki pendidikan terakhir S2. Sebagian besar responden (28\%) sudah bekerja lebih dari 6 tahun, sisanya $13 \%$ bekerja selama 1 tahun, 24\% bekerja selama 2 tahun, 12\% bekerja selama 3 tahun, $15 \%$ bekerja selama 4 tahun, dan $8 \%$ bekerja selama 5 tahun. 


\section{Analisis Deskripsi Variabel Penelitian}

Tabel 1 Rata-rata skor variabel

\begin{tabular}{lcc}
\hline \multicolumn{1}{c}{ Variabel } & Rata-rata skor total & Kategori \\
\hline Kompensasi & 3,93 & Tinggi \\
Motivasi & 3,87 & Tinggi \\
Kinerja Karyawan & 3,86 & Tinggi \\
\hline
\end{tabular}

Sumber: data primer diolah, 2018

Tabel 1 menunjukkan bahwa rata-rata skor total untuk variabel kompensasi adalah sebesar 3,93 dan masuk dalam kategori tinggi. Hal ini berarti karyawan merasa puas dengan gaji, tunjangan-tunjangan, dan insentif yang diberikan oleh perusahaan. Karyawan juga merasa terlindungi dengan adanya fasilitas kesehatan dan merasa nyaman dengan fasilitas keamanan yang disediakan perusahaan. Selain itu, karyawan juga merasa senang dengan pujian yang diberikan oleh perusahaan dan pemimpin memberikan penghargaan kepada karyawan yang berprestasi tinggi.

Rata-rata skor total untuk variabel motivasi adalah sebesar 3,87 dan masuk dalam kategori tinggi. Hal ini berarti karyawan memiliki persepsi bahwa 1) pihak perusahaan peduli atas pencapaian prestasi kerja karyawan, 2) promosi kerja dan kenaikan pangkat dilakukan berdasarkan kemampuan dan prestasi kerja karyawa, 3) penilaian prestasi kerja karyawan sudah dilakukan secara obyektif dan prestasi yang diraih karyawan saat ini sudah memuaskan, 4) karyawan akan merasa puas jika pekerjaan dapat diselesaikan dan bersedia lembur untuk menyelesaikannya, 5) karyawan selalu memeriksa kembali pekerjaannya sebagai bentuk tanggung jawab dan mendiskusikan kepada atasan jika belum memahami pekerjaan, 6) pekerjaan saat ini membantu untuk meningkatkan karir di masa depan sehingga karyawan lebih memilih mengembangkan kemampuan dibanding insentif uang, 7) pimpinan memberikan pelatihan bagi karyawan untuk meningkatkan kemampuan dan pelatihan tersebut bermanfaat untuk pengembangan karir, 8) karyawan giat bekerja karena adanya kesempatan untuk mendapatkan posisi tertentu, 9) perlu memiliki hubungan yang baik dengan pimpinan dan rekan kerja untuk mendukung pengembangan karir, 10) karyawan mendapat pengakuan dan penghargaan dari pimpinan dan rekan kerja saat berhasil menyelesaikan pekerjaan, 11) pimpinan selalu memberikan pujian bilamana terdapat pegawai yang mampu menyelesaikan pekerjaan dengan memuaskan, 12) pengakuan atas prestasi kerja mampu memotivasi pegawai untuk berprestasi, 13) karyawan sering dilibatkan dalam pengambilan keputusan dan 
kegiatan perusahaan, 14) setiap tugas pekerjaan yang dikerjakan harus dilandasi rasa senang, loyalitas, dan tanggung jawab organisasi yang tingg, dan 15) karyawan merasa diberikan keleluasaan untuk melakukan pekerjaannya.

Variabel kinerja karyawan memiliki rata-rata skor total sebesar 3,86 dan masuk kategori tinggi. Hal ini berarti karyawan memiliki persepsi bahwa dia dapat mencapai standar kualitas yang telah ditetapkan perusahaan, menghasilkan kualitas pekerjaan yang lebih baik dibandingkan rekan kerja maupun pekerjaan sebelumnya. Selain itu, dia juga berusaha lebih baik dibandingkan rekan kerja, dapat menyelesaikan pekerjaan sesuai dengan waktu yang telah ditentukan perusahaan, dan lebih cepat dari sebelumnya.

\section{Pengujian Instrumen}

\section{Uji Validitas}

Tabel 2 Hasil Uji Validitas

\begin{tabular}{cccc}
\hline Variabel & r hitung & r tabel & Keterangan \\
\hline Kompensasi & $0,403-0,756$ & 0,3610 & Valid \\
Motivasi & $0,365-0,698$ & 0,3610 & Valid \\
Kinerja karyawan & $0,557-0,877$ & 0,3610 & Valid \\
\hline \multicolumn{4}{c}{ Sumber: Data diolah, 2018}
\end{tabular}

Menurut Sukardi (2013) validitas adalah derajat yang menunjukkan dimana suatu tes mengukur apa yang hendak diukur. Uji validitas digunakan untuk menghitung korelasi antara masing-masing pernyataan dengan skor total menggunakan rumus Pearson Product Moment (Bungin, 2011:207). Penelitian ini menggunakan $\alpha=5 \%$ sehingga syarat suatu instrumen dikatakan valid adalah jika nilai $\mathrm{r}$ hitung > $\mathrm{r}$ tabel dengan taraf keyakinan 95\%. Berdasarkan tabel 2, dapat dilihat bahwa nilai $r$ hitung seluruh item pernyataan lebih besar dari $r$ tabel sehingga dapat ditarik kesimpulan bahwa seluruh item pernyataan pada penelitian ini valid.

\section{Uji Reliabilitas}

Tabel 3 Hasil Uji Reliabilitas

\begin{tabular}{clcc}
\hline No. & \multicolumn{1}{c}{ Variabel } & Cronbach's Alpha & Keterangan \\
\hline 1 & Kompensasi & 0,732 & Reliabel \\
2 & Motivasi & 0,745 & Reliabel \\
3 & Kinerja Karyawan & 0,790 & Reliabel \\
\hline
\end{tabular}

Sumber: Data diolah, 2018 
Uji reliabilitas adalah derajat konsistensi dan stabilitas data atau temuan. Suatu data dikatakan reliabel apabila dua atau lebih penelitian dalam objek yang sama menghasilkan data yang sama atau sekolompok data bila dipecah menjadi dua menunjukkan data yang tidak berbeda. Dalam penelitian ini variabel dikatakan reliabel jika Cronbach Alpha >0,60.

Berdasarkan tabel 3 dapat dilihat bahwa semua variabel mempunyai nilai Cronbach Alpha di atas 0,60 sehingga dapat ditarik kesimpulan bahwa semua variabel pada kuisioner dalam penelitian ini reliabel sebagai alat ukur.

\section{Uji Asumsi Klasik}

Uji asumsi klasik dilakukan untuk mengetahui apakah model regresi yang dibuat dapat digunakan sebagai alat prediksi yang baik. Uji asumsi klasik yang dilakukan dalam penelitian ini adalah uji normalitas, uji heteroskedastisitas, dan uji multikolinearitas.

\section{Uji Normalitas}

Menurut Ghozali (2011:160-165) uji normalitas bertujuan untuk menguji apakah di dalam model regresi variabel independent dan variabel dependent diantara keduanya mempunyai distribusi yang normal atau tidak. Model regresi yang baik harus memiliki distribusi normal atau mendekati normal. Uji normalitas dalam penelitian ini dilakukan dengan One Sample Kolmogorov-Smirnov. Jika angka sig. Uji K-S > 0,05 maka dapat disimpulkan bahwa residual menyebar normal.

Tabel 4 Hasil Uji Nomalitas

\begin{tabular}{ccccc}
\hline Variabel & $\mathrm{N}$ & $\mathrm{Sig}$ & $\mathrm{Std}$ & Keterangan \\
\hline $\begin{array}{c}\text { Unstandardized } \\
\text { residual }\end{array}$ & 100 & 0,056 & $>0,05$ & $\begin{array}{c}\text { Berdistribusi } \\
\text { Normal }\end{array}$ \\
\hline
\end{tabular}

Sumber: Data diolah, 2018

Nilai signifikansi pada tabel 4 sebesar 0,056 dan lebih besar dari 0,05 sehingga dapat disimpulkan bahwa residual berdistribusi normal.

\section{Uji Multikolinearitas}

Menurut Ghozali (2011: 105-106) uji multikolinearitas bertujuan untuk menguji apakah model regresi ditemukan adanya korelasi antar variabel bebas, 
regresi yang baik memiliki syarat tidak ada multikolinearitas. Jika nilai VIF lebih besar 10, maka terjadi multikolinearitas di antara variabel bebas. Sebaliknya, jika nilai VIF lebih kecil atau kecil sama dari 10, maka tidak terjadi multikolinearitas di antara variabel bebas.

Tabel 5. Hasil Uji Multikolinearitas

\begin{tabular}{cccc}
\hline Variabel & VIF & Std & Keterangan \\
\hline Kompensasi & 1,921 & $<10$ & Tidak terjadi multikolinearitas \\
Motivasi & 1,921 & $<10$ & Tidak terjadi multikolinearitas \\
\hline
\end{tabular}

Sumber: Data diolah, 2018

Nilai VIF variabel kompensasi dan motivasi pada table 5 sebesar 1,921 dan lebih kecil dari 10, sehingga dapat disimpulkan bahwa tidak ada multikolinearitas di antara variabel bebas tersebut.

\section{Uji Heteroskedastisitas}

Menurut Ghozali (2011: 139-143) uji heteroskedastisitas bertujuan untuk menguji apakah dalam model regresi terjadi ketidaksamaan varian dari residual satu pengamatan ke pengamatan lain. Dasar pengambilan keputusan dalam uji heteroskedastisitas dengan grafik scatterplot yaitu jika terdapat pola tertentu pada grafik scatterplot SPSS, seperti titik-titik yang membentuk pola teraturmaka dapat disimpulkan bahwa telah terjadi heteroskedastisitas.

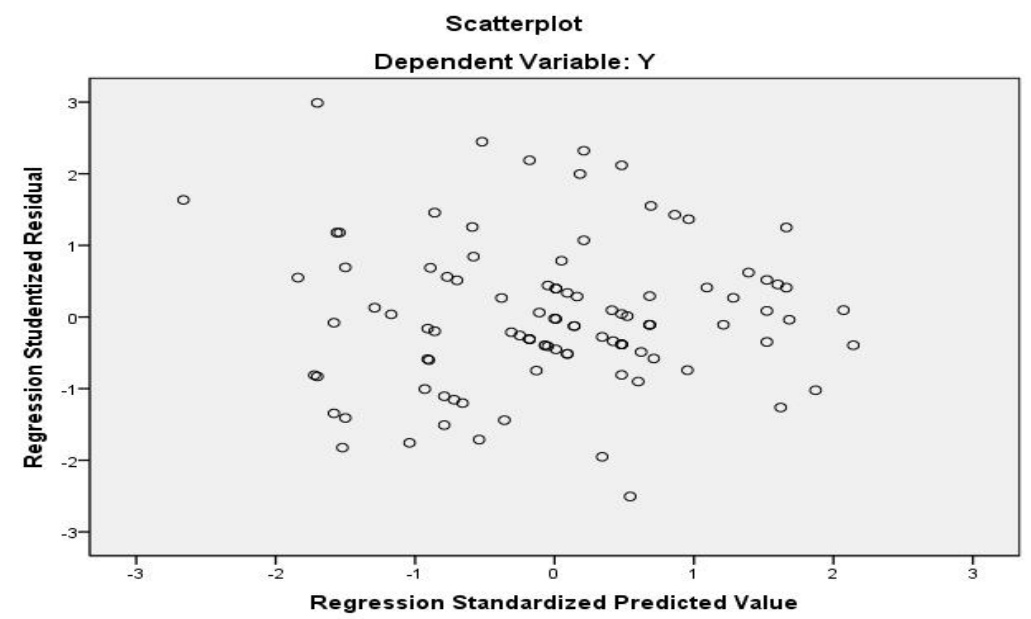

Gambar 2 . Hasil Uji Heteroskedastisitas 
Berdasarkan gambar 2 dapat dilihat bahwa titik-titik pada grafik Scatterplot menyebar merata tanpa membentuk pola tertentu. Maka dapat disimpulkan bahwa data yang diuji dalam penelitian ini tidak mengalami heteroskedastisitas.

\section{Analisis Linear Berganda}

Analisis ini digunakan untuk mengetahui pengaruh kompensasi dan motivasi terhadap kinerja karyawan. Tabel 6 berikut ini menunjukkan output regresi linier dengan program SPSS versi 19.

Tabel 6 Hasil Uji Regresi Linear Berganda

\begin{tabular}{|c|c|c|c|c|c|c|c|}
\hline Keterangan & $\mathrm{R}$ & $\mathrm{R}^{2}$ & $\begin{array}{l}\text { Unstandardized } \\
\text { Coeficients }(\beta)\end{array}$ & Nilai t & $\mathrm{F}$ & Sig & Keterangan \\
\hline $\begin{array}{l}\text { Ringkasan } \\
\text { model }\end{array}$ & 0,619 & 0,383 & 1,200 & & 30,117 & 0,000 & $\begin{array}{l}\mathrm{H} 3 \\
\text { terdukung }\end{array}$ \\
\hline Kompensasi & & & $-0,003$ & $-0,030$ & & 0,976 & $\begin{array}{l}\text { H1 tidak } \\
\text { terdukung }\end{array}$ \\
\hline Motivasi & & & 0,689 & 5,620 & & 0,000 & $\begin{array}{l}\mathrm{H} 2 \\
\text { terdukung }\end{array}$ \\
\hline
\end{tabular}

Sumber: Data Primer Diolah, 2018

\section{Uji Hipotesis}

Uji F

Uji F digunakan untuk mengetahui pengaruh variabel bebas yaitu kompensasi dan motivasi secara bersama-sama berpengaruh signifikan terhadap variabel terikat kinerja karyawan. Tahap yang digunakan untuk melakukan uji F sebagai berikut:

1. Menentukan $\mathrm{H}_{0}$ dan $\mathrm{H}_{\mathrm{a}}$

a. $\mathrm{H}_{0}$ : kompensasi dan motivasi secara bersama-sama tidak berpengaruh signifikan terhadap kinerja karyawan.

b. Ha: kompensasi dan motivasi secara bersama-sama berpengaruh signifikan terhadap kinerja karyawan

2. Menentukan tingkat signifikansi $(\alpha)$ dan $\mathrm{F}$ tabel

Tingkat signifikansi menggunakan $\alpha=5 \%$ atau 0,05 yang merupakan ukuran standar untuk digunakan dalam sebuah penelitian

3. Menentukan $F_{\text {hitung }}$ dan $F_{\text {tabel }}$ 
$\mathrm{F}$ hitung diperoleh melalui output SPSS yaitu sebesar 30,117. F tabel sebesar 3,09 diperoleh pada signifikansi $5 \%$ dan $\mathrm{n}-\mathrm{k}=98$.

4. Menentukan kriteria uji $\mathrm{F}$

a. $\mathrm{H}_{0}$ diterima dan $\mathrm{H}_{\mathrm{a}}$ ditolak jika $\mathrm{F}_{\text {hitung }} \leq \mathrm{F}_{\text {tabel }}$ atau sig. $>0,05$

b. $\mathrm{H}_{\mathrm{a}}$ diterima dan $\mathrm{H}_{0}$ ditolak jika $\mathrm{F}_{\text {hitung }}>\mathrm{F}$ tabel atau sig $<0,05$

5. Kesimpulan

Berdasarkan tabel 6 dapat dilihat nilai $F$ hitung sebesar 30,117 lebih besar dari nilai $\mathrm{F}$ tabel sebesar 3,09 $(30,117>3,09)$ serta nilai signifikansi sebesar 0,000 < 0,05 sehingga $\mathrm{H}_{\mathrm{a}}$ diterima dan $\mathrm{H}_{0}$ ditolak. Hal ini berarti kompensasi dan motivasi secara bersama-sama berpengaruh signifikan terhadap kinerja karyawan.

Uji t

Uji t digunakan untuk menguji apakah variabel kompensasi dan variabel motivasi berpengaruh secara parsial terhadap varibel dependen yaitu kinerja karyawan. Tahap yang digunakan untuk melakukan uji t sebagai berikut:

1. Menentukan $\mathrm{H}_{0}$ dan $\mathrm{H}_{\mathrm{a}}$

a. $\mathrm{H}_{0}$ : Kompensasi dan motivasi secara parsial tidak berpengaruh positif dan signifikan terhadap kinerja karyawan

b. $\mathrm{H}_{\mathrm{a}}$ : Kompensasi dan motivasi secara parsial berpengaruh positif dan signifikan terhadap kinerja karyawan

2. Menentukan taraf signifikansi

Taraf signifikan atau $\alpha$ (alpha) yang digunakan di dalam penelitian adalah 5\% atau 0,05 .

3. Menentukan $t_{\text {hitung }}$

Besarnya nilai $\mathrm{t}$ hitung untuk variabel kompensasi adalah sebesar -0,030 sedangkan untuk variable motivasi adalah sebesar 5,620. $\mathrm{t}$ tabel sebesar 1,985 diperoleh pada signifikansi 0,05 dan $n-k-1=97$

4. Kriteria pengujian

a. $\mathrm{H}_{0}$ ditolak dan $\mathrm{H}_{\mathrm{a}}$ diterima jika $\mathrm{t}$ hitung $>\mathrm{t}$ tabel atau sig. $<0,05$

b. $\mathrm{H}_{0}$ diterima dan $\mathrm{H}_{\mathrm{a}}$ ditolak jika $\mathrm{t}$ hitung $\leq \mathrm{t}$ tabel atau sig. $\geq 0,0$

5. Kesimpulan 
Berdasarkan hasil uji regresi pada tabel 6 dapat dilihat bahwa nilai sig. pada variabel kompensasi lebih besar dari 0,05 (0,976>0,05) sehingga kompensasi tidak berpengaruh positif dan signifikan terhadap kinerja karyawan. Sedangkan nilai sig. variabel motivasi lebih kecil dari $0,05(0,00<0,05)$ sehingga motivasi berpengaruh positif dan signifikan terhadap kinerja karyawan.

\section{Nilai koefisien determinasi}

Tabel 6 menunjukkan nilai $\mathrm{R}^{2}$ sebesar 0,383. Ini berarti kinerja karyawan dipengaruhi oleh kompensasi dan motivasi sebesar 38,3\% sedangkan sisanya 61,7\% dipengaruhi oleh faktor lain di luar kompensasi dan motivasi.

\section{Pengaruh kompensasi terhadap kinerja karyawan}

Berdasarkan hasil analisis regresi diketahui bahwa kompensasi tidak memiliki pengaruh positif dan signifikan terhadap kinerja karyawan karena nilai signifikansi variabel kompensasi sebesar $(0,976)>0,05$. Hal ini berarti tinggi rendah kompensasi yang diberikan tidak akan mempengaruhi kinerja karyawan. Menurut Sofyandi (2008), kompensasi dikelompokkan menjadi kompensasi langsung dan kompensasi tidak langsung. Kompensasi langsung adalah suatu balas jasa yang diberikan kepada karyawan karena telah memberikan prestasinya demi kepentingan perusahaan dengan contoh gaji dan insentif. Sedangkan kompensasi tidak langsung adalah pemberian kompensasi kepada karyawan sebagai tambahan yang didasarkan kepada kebijakan pemimpin dalam rangka upaya meningkatkan kesejahteraan karyawan misalnya tunjangan hari raya, tunjangan pensiun, dan fasilitas yang diberikan perusahaan. PT DIPA Pharmalan Intersains Jakarta memberikan kompensasi langsung berupa gaji kepada semua karyawan. Insentif tidak hanya diberikan kepada bagian sales dan marketing, tetapi terdapat beberapa divisi support yang berhak atas insentif diantaranya HRD recruitment, dan bussines development. Adanya kebijakan yang berbeda perihal pemberian kompensasi langsung berupa insentif mengakibatkan kompensasi tidak berpengaruh terhadap kinerja karyawan.

Hasil penelitian ini selaras dengan penelitian di CV Cynthia Box Kudus oleh Utami, Rodhiyah, dan Nurseto (2015) yang menyatakan bahwa kompensasi 
tidak berpengaruh terhadap kinerja karyawan dengan nilai t hitung kompensasi sebesar $(1,756)<\mathrm{t}$ tabel $(2,016)$. Hal tersebut dikarenakan karyawan merasa sistem imbalan yang diberikan sudah sesuai ketentuan UMR Kudus. Sedangkan hasil penelitian ini berbeda dengan penelitian di PT Coca Cola Distribution Indonesia Banjarbaru oleh Sugiannor pada tahun 2014 yang menyatakan bahwa kompensasi berpengaruh terhadap kinerja karyawan. Hal tersebut dikarenakan kompensasi merupakan faktor yang berpengaruh dominan terhadap kinerja karyawan, sehingga jika ada peningkatan pemberian kompensasi akan meningkatkan kinerja karyawan dan juga kompensasi memiliki menjadi salah satu tujuan utama karyawan dalam mencukupi berbagai kebutuhan.

\section{Pengaruh Motivasi Terhadap Kinerja Karyawan}

Motivasi berpengaruh positif dan signifikan terhadap kinerja karyawan karena nilai signifikansi variabel motivasi sebesar $0,000<0,05$ sehingga dapat diartikan bahwa motivasi sudah berhasil mendorong kinerja karyawan menjadi semakin meningkat. Semakin tinggi motivasi semakin tinggi pula kinerja karyawan. Hal ini didukung oleh pernyataan kuesioner "pihak perusahaan peduli atas pencapaian prestasi kerja karyawan" dengan mean 4,17 yang berarti bahwa perusahaan berhasil mendorong karyawan untuk memiliki motivasi yang tinggi. Hal tersebut sesuai dengan teori (Herzberg) dikutip dalam Hasibuan (2009) yang menyatakan bahwa daya dorong datang dari luar diri seseorang, terutama dari organisasi tempatnya bekerja. Hasil penelitian ini selaras dengan penelitian sebelumnya oleh Wijaya dan Andreani tahun 2015 di PT Tunas Jaya Abadi Bersama dengan hasil motivasi berpengaruh terhadap kinerja karyawan. Sedangkan hasil penelitian ini berbeda dengan penelitian sebelumnya di PT Tunas Hijau Samarinda oleh Suwati tahun 2013 yang menyatakan bahwa motivasi secara parsial tidak berpengaruh positif dan signifikan terhadap kinerja karyawan. Hal tersebut disebabkan karena karyawan kurang bangga dan puas dengan perusahaan tersebut, sehingga intensitas karyawan yang mengundurkan diri meningkat. 


\section{Pengaruh Kompensasi dan Motivasi Terhadap Kinerja Karyawan}

Hasil perhitungan analisis regresi linier pada tabel 6 menunjukkan bahwa nilai signifikasi sebesar $0,00<0,05$ dan nilai $F$ hitung sebesar 30,117 > 3,09 (F tabel). Ini berarti kompensasi dan motivasi memiliki pengaruh secara bersama-sama terhadap kinerja karyawan, semakin tinggi kompensasi yang diberikan oleh perusahaan dan semakin tinggi motivasi yang dimiliki karyawan maka kinerja karyawan akan semakin tinggi. Pemberian kompensasi dan motivasi secara seimbang kepada karyawan tentu akan membuat karyawan tetap mempertahankan kinerja mereka, sehingga kompensasi dan motivasi secara bersama-sama berpengaruh terhadap kinerja karyawan PT DIPA Pharmalab Intersains Jakarta. Hasil penelitian ini selaras dengan penelitian Wijaya dan Andreani (2015) di PT Sinar Jaya Abadi Bersama, Suwati (2013) di PT Tunas Hijau Samarinda, dan Sugiannor (2014) di PT Coca Cola yang menyatakan kompensasi dan motivasi berpengaruh terhadap kinerja karyawan. Selain itu, hasil penelitian ini juga selaras dengan pernyataan Simanjuntak (dalam Widodo, 2015:133) bahwa kompensasi dan motivasi merupakan faktor yang mempengaruhi kinerja karyawan. Oleh karena itu, dapat diartikan bahwa kinerja karyawan akan semakin tinggi jika adanya motivasi dan kompensasi tinggi.

\section{Kesimpulan, Implikasi, Saran dan Keterbatasan}

Berdasarkan hasil penelitian dapat ditarik kesimpulan bahwa 1) kompensasi tidak berpengaruh positif terhadap kinerja karyawan, 2) motivasi berpengaruh positif terhadap kinerja karyawan, dan 3) kompensasi dan motivasi secara bersama-sama berpengaruh terhadap kinerja karyawan.

Kompensasi tidak berpengaruh positif terhadap kinerja karyawan PT DIPA Pharmalab Intersains Jakarta sehingga perusahaan sebaiknya mengevaluasi kebijakan pemberian kompensasi khususnya insentif kepada pihak-pihak yang bertanggung jawab dan menjaga konsistensi indeks pencapaian kepuasaan karyawan di atas ratarata objektif. Perusahaan perlu melakukan survei khusus mengenai kompensasi yang diberikan kepada karyawan sehingga dapat menjadi pertimbangan perusahaan dalam memutuskan pemberian kompensasi yang layak. Selain itu, perusahaan sebaiknya tetap mempertahankan memotivasi karyawan, misal dengan memberi penghargaan kepada karyawan berprestasi sehingga akan tercipta motivasi kerja yang lebih tinggi. 
Hal ini karena motivasi berpengaruh positif terhadap kinerja karyawan. Peneliti selanjutnya dapat menggunakan variabel-variabel lain yang mendukung kinerja karyawan seperti budaya organisasi, lingkungan kerja, dan gaya kepemimpinan, serta subyek penelitian yang diambil sebaiknya focus pada divisi tertentu.

\section{Referensi}

Ardana, I Komang, Ni W Muljati, dan I W Mudiartha. 2012. Manajemen Sumber Daya Manusia. Yogyakarta: Penerbit Graha Ilmu.

Arzani, L.A., Suryadi Poerbo, dan Dody Setyadi. 2018. Pengaruh Motivasi Kerja, Kompensasi Dan Lingkungan Kerja Terhadap Kinerja Karyawan (Studi Kasus Bagian Operasional PT. Jasco Logistics). Journal Admisi dan Bisnis. Vol. 19 (2). 119-126.

Bungin, Burhan. 2011. Metodologi Penelitian Kuantitatif. Jakarta: Kencana.

Ghozali, Imam. 2011. Aplikasi Analisis Multivariate dengan Program SPSS. Semarang: Penerbit Universitas Diponegoro.

Hariandja, Marihot T.E, 2002. Manajemen Sumber Daya Manusia. Jakarta: Grasindo.

Hasibuan, Malayu S.P. 2009. Manajemen Sumber Daya Manusia. Jakarta: Bumi Aksara.

Moeheriono. 2012. Pengukuran Kinerja Berbasis Kompetensi. Jakarta: Raja Grafindo Persada. No. 2, hlm. 28 - 31.

Moorhead, G. dan Ricky W. Griffin. 2013. Perilaku Organisasi Manajemen Sumber Daya Manusia dan Organisasi. Jakarta : Salemba Empat.

Patton, MQ. 2009. Metode Evaluasi Kualitatif. Jakarta: Pustaka Pelajar.

Rivai, H.V. dan Sagala, E. J. 2011. Manajemen Sumber Daya Manusia Untuk Perusahaan Dari Teori Ke Praktik Edisi 2. Jakarta: Rajawali Pers.

Widodo, Suparno Eko. 2015. Manajemen Pengembangan Sumber Daya Manusia. Yogyakarta: Pustaka Pelajar.

Samsudin, Sadili. 2010. Manajemen Sumber Daya Manusia. Bandung: Pustaka Setia. Siswanto. 2010. Pengantar Manajemen. Jakarta: Bumi Aksara.

Sofyandi, Herman. 2008. Manajemen Sumber Daya Manusia.Yogyakarta: Graha Ilmu.

Sugiannor. 2014. "Pengaruh Kompensasi dan Motivasi Kerja Terhadap Kinerja Karyawan Pemasaran PT COCA COLA Distribution Indonesia Sales Office Banjarbaru ". KINDAI. Vol 10 (4), 257 - 268.

Sukardi. 2013. Metodologi Penelitian Pendidikan dan Pengembangan. Jakarta: Aksara.

Sunyoto, Danang. 2012. Manajemen Sumber Daya Manusia. Jakarta: PT Buku Seru.

Sutrisno, Edy. 2010. Manajemen Sumber Daya Manusia. Jakarta: Kencana Prenada Media Group.

Suwati, Yulia. 2013. "Pengaruh Kompensasi dan Motivasi Kerja Terhadap Kinerja Karyawan pada PT. Tunas Hijau Samarinda”. Jurnal Ilmu Administrasi Bisnis. Vol 1(1), 41-55.

Sunyoto, Danang. 2012. Manajemen Sumber Daya Manusia. Jakarta: PT Buku Seru. 
Utami, Dewi Putri, Rodhiyah, dan Sendhang Nurseto. 2015. "Pengaruh Lingkungan Kerja dan Kompensasi Terhadap Kinerja Karyawan Bagian Produksi Pada CV Cynthia Box Kudus". Jurnal Administrasi Bisnis. Vol 5 (1), 134-144

Wijaya, Tanto, dan Fransisca Andreani. 2015. "Pengaruh Motivasi dan Kompensasi Terhadap Kinerja Karyawan PT Sinar Jaya Abadi Bersama". AGORA. Vol 3 (2), 37-45

\section{Lampiran}

\section{Analisis Deskriptif Variabel}

\section{Variabel Kompensasi}

\begin{tabular}{|c|c|c|c|}
\hline Item & Pernyataan & Mean & Kategori \\
\hline 1 & $\begin{array}{l}\text { Saya merasa puas dengan gaji yang ditetapkan } \\
\text { perusahaan }\end{array}$ & 3,83 & Tinggi \\
\hline 2 & $\begin{array}{l}\text { Saya mendapatkan gaji atas pekerjaan yang dilakukan } \\
\text { secara tepat }\end{array}$ & 4,30 & $\begin{array}{l}\text { Sangat } \\
\text { Tinggi }\end{array}$ \\
\hline 3 & $\begin{array}{l}\text { Saya merasa puas dengan tunjangan-tunjangan yang } \\
\text { diberikan oleh perusahaan. }\end{array}$ & 3,66 & Tinggi \\
\hline 4 & $\begin{array}{l}\text { Saya merasa puas dengan insentif yang ditetapkan } \\
\text { perusahaan }\end{array}$ & 3,48 & Tinggi \\
\hline 5 & $\begin{array}{l}\text { Pemimpin memberikan penghargaan kepada karyawan } \\
\text { yang berprestasi tinggi }\end{array}$ & 4,10 & Tinggi \\
\hline 6 & $\begin{array}{l}\text { Saya merasa senang dengan pujian yang diberikan } \\
\text { perusahaan }\end{array}$ & 4,02 & Tinggi \\
\hline 7 & $\begin{array}{l}\text { Saya merasa terlindungi dengan adanya fasilitas } \\
\text { kesehatan yang diberikan perusahaan }\end{array}$ & 4,06 & Tinggi \\
\hline \multirow[t]{2}{*}{8} & $\begin{array}{l}\text { Saya merasa nyaman dengan fasilitas keamanan yang } \\
\text { disediakan perusahaan. }\end{array}$ & 3,99 & Tinggi \\
\hline & Total Mean & 3,93 & Tinggi \\
\hline
\end{tabular}

\section{Variabel Motivasi}

\begin{tabular}{|c|c|c|}
\hline Item & Pernyataan & Mean \\
\hline 1 & Pihak perusahaan peduli atas pencapaian prestasi kerja karyawan & 4,17 \\
\hline 2 & $\begin{array}{l}\text { Promosi kerja dan kenaikan pangkat dilakukan berdasarkan } \\
\text { kemampuan dan prestasi kerja karyawan }\end{array}$ & 3,99 \\
\hline 3 & Penilaian prestasi kerja karyawan sudah dilakukan secara obyektif & 3,73 \\
\hline 4 & Prestasi yang anda raih saat ini sudah memuaskan & 3,54 \\
\hline 5 & Saya masih belum puas jika pekerjaan belum dapat diselesaikan & 4,07 \\
\hline 6 & $\begin{array}{l}\text { Saya selalu memeriksa kembali pekerjaan saya sebagai bentuk } \\
\text { tanggung jawab. }\end{array}$ & 4,14 \\
\hline 7 & $\begin{array}{l}\text { Saya mendiskusikan kepada atasan jika belum memahami pekerjaan } \\
\text { saya }\end{array}$ & 3,98 \\
\hline 8 & $\begin{array}{l}\text { Jika waktu yang diberikan untuk menyelesaikan pekerjaan tidak } \\
\text { cukup, maka saya akan lembur }\end{array}$ & 3,82 \\
\hline 9 & $\begin{array}{l}\text { Pekerjaan saya saat ini membantu untuk meningkatkan karir di } \\
\text { masa depan }\end{array}$ & 3,88 \\
\hline 10 & Saya lebih memilih mengembangkan kemampuan saya dibanding & 3,64 \\
\hline
\end{tabular}




\begin{tabular}{|c|c|c|}
\hline & insentif uang. & \\
\hline 11 & $\begin{array}{l}\text { Pimpinan memberikan pelatihan bagi karyawan untukmeningkatkan } \\
\text { kemampuan. }\end{array}$ & 3,92 \\
\hline 12 & $\begin{array}{l}\text { Pelatihan yang saya ikuti dapat bermanfaat untuk pengembangan } \\
\text { karir. }\end{array}$ & 4,08 \\
\hline 13 & $\begin{array}{l}\text { Saya giat bekerja karena adanya kesempatan untuk mendapatkan } \\
\text { posisi tertentu }\end{array}$ & 3,79 \\
\hline 14 & $\begin{array}{l}\text { Saya memiliki hubungan yang baik dengan pimpinan dan rekan } \\
\text { kerja untuk mendukung pengembangan karir }\end{array}$ & 3,92 \\
\hline 15 & $\begin{array}{l}\text { Saya mendapat pengakuan dan penghargaan dari pimpinan dan } \\
\text { rekan kerja saat berhasil menyelesaikan pekerjaan }\end{array}$ & 3,82 \\
\hline 16 & $\begin{array}{l}\text { Pimpinan selalu memberikan pujian bilamana terdapat pegawai } \\
\text { yang mampu menyelesaikan pekerjaan dengan memuaskan. }\end{array}$ & 3,8 \\
\hline 17 & $\begin{array}{l}\text { Pengakuan atas prestasi kerja mampu memotivasi pegawai untuk } \\
\text { berprestasi }\end{array}$ & 3,95 \\
\hline 18 & $\begin{array}{l}\text { Saya sering dilibatkan dalam pengambilan keputusan dan kegiatan } \\
\text { perusahaan }\end{array}$ & 3,59 \\
\hline 19 & $\begin{array}{l}\text { Setiap tugas pekerjaan yang dikerjakan harus dilandasi rasa senang, } \\
\text { loyalitas, dan tanggung jawab organisasi yang tinggi }\end{array}$ & 3,98 \\
\hline 20 & Saya merasa diberikan keleluasaan untuk melakukan pekerjaan saya & 3,75 \\
\hline & Total Mean & 3,87 \\
\hline
\end{tabular}

\section{Variabel Kinerja Karyawan}

\begin{tabular}{llc}
\hline Item & \multicolumn{1}{c}{ Pernyataan } & Mean \\
\hline 1 & $\begin{array}{l}\text { Saya dapat mencapai standar kualitas yang telah ditetapkan } \\
\text { perusahaan dengan baik }\end{array}$ & 3,92 \\
2 & $\begin{array}{l}\text { Saya berusaha menghasilkan kualitas pekerjaan yang lebih baik } \\
\text { dibandingkan rekan kerja }\end{array}$ & 3,90 \\
3 & $\begin{array}{l}\text { Hasil pekerjaan saya lebih baik bila dibandingkan dengan } \\
\text { sebelumnya }\end{array}$ & 3,87 \\
4 & $\begin{array}{l}\text { Selama bekerja saya berusaha lebih baik dibandingkan rekan kerja } \\
\text { Seluruh pekerjaan dapat saya selesaikan sesuai dengan waktu yang } \\
\text { telah ditentukan perusahaan. }\end{array}$ & 3,86 \\
& $\begin{array}{l}\text { Saya dapat menyelesaikan pekerjaan dengan lebih cepat dari } \\
\text { sebelumnya }\end{array}$ & 3,84 \\
\hline & Total Mean & 3,86 \\
\hline
\end{tabular}




\section{Hasil Uji Validitas}

Hasil Uji Validitas Variabel Kompensasi

\begin{tabular}{cc}
\hline Pernyataan & r hitung \\
\hline 1 & 0,756 \\
2 & 0,545 \\
3 & 0,403 \\
4 & 0,545 \\
5 & 0,540 \\
6 & 0,672 \\
7 & 0,604 \\
8 & 0,414 \\
\hline
\end{tabular}

Hasil Uji Validitas Variabel Motivasi

\begin{tabular}{cc}
\hline Pernyataan & r hitung \\
\hline 1 & 0,365 \\
2 & 0,667 \\
3 & 0,505 \\
4 & 0,698 \\
5 & 0,655 \\
6 & 0,667 \\
7 & 0,478 \\
8 & 0,692 \\
9 & 0,616 \\
10 & 0,609 \\
11 & 0,443 \\
12 & 0,546 \\
13 & 0,475 \\
14 & 0,665 \\
15 & 0,377 \\
16 & 0,390 \\
17 & 0,667 \\
18 & 0,505 \\
19 & 0,667 \\
20 & 0,623 \\
\hline
\end{tabular}


Hasil Uji Validitas Variabel Kinerja Karyawan

\begin{tabular}{cc}
\hline Pernyataan & r hitung \\
\hline 1 & 0,877 \\
2 & 0,557 \\
3 & 0,872 \\
4 & 0,557 \\
5 & 0,826 \\
6 & 0,823 \\
\hline
\end{tabular}

\section{Hasil Uji Asumsi Klasik}

\section{Uji Normalitas}

One-Sample Kolmogorov-Smirnov Test

\begin{tabular}{|c|c|c|}
\hline & & Unstandardized Residual \\
\hline $\mathrm{N}$ & & 100 \\
\hline \multirow{2}{*}{ Normal Parameters ${ }^{\mathrm{a}, \mathrm{b}}$} & Mean & .0000000 \\
\hline & Std. Deviation & .33344113 \\
\hline \multirow{3}{*}{$\begin{array}{l}\text { Most } \\
\text { Differences }\end{array}$} & Absolute & .134 \\
\hline & Positive & .094 \\
\hline & Negative & -.134 \\
\hline Kolmogorov-Smirnov Z & & 1.338 \\
\hline Asymp. Sig. (2-tailed) & & .056 \\
\hline
\end{tabular}

a. Test distribution is Normal.

b. Calculated from data.

\section{Uji Multikolinearitas}

\begin{tabular}{llrrrrr}
\hline & & \multicolumn{3}{c}{$\begin{array}{c}\text { Unstandardized } \\
\text { Coefficients }\end{array}$} & \multicolumn{2}{c}{ Collinearity Statistics } \\
\cline { 3 - 7 } Model & \multicolumn{2}{c}{ B } & Std. Error & Tolerance & VIF \\
\hline 1 & (Constant) & 1.200 & .354 & & \\
& Kompensasi & -.003 & .104 & .520 & 1.921 \\
& Motivasi & .689 & .123 & .520 & 1.921 \\
\hline
\end{tabular}




\section{Output Regresi Linier Berganda}

\begin{tabular}{|c|c|c|c|c|c|c|}
\hline \multicolumn{7}{|c|}{ Coefficients $^{\mathrm{a}}$} \\
\hline \multirow[t]{2}{*}{ Model } & & \multicolumn{2}{|c|}{ Unstandardized Coefficients } & $\begin{array}{l}\text { Standardized } \\
\text { Coefficients }\end{array}$ & \multirow[t]{2}{*}{$\mathrm{t}$} & \multirow[t]{2}{*}{ Sig. } \\
\hline & & $\mathrm{B}$ & Std. Error & Beta & & \\
\hline \multirow[t]{3}{*}{1} & (Constant) & 1.200 & .354 & & 3.389 & .001 \\
\hline & Kompensasi & -.003 & .104 & -.003 & -.030 & .976 \\
\hline & Motivasi & .689 & .123 & .621 & 5.620 & .000 \\
\hline
\end{tabular}

a. Dependent Variable: Kinerja Karyawan

ANOVA $^{\mathrm{a}}$

\begin{tabular}{llrrrrr}
\hline Model & & Sum of Squares & Df & Mean Square & F & Sig. \\
\hline 1 & Regression & 6.835 & 3 & 3.418 & 30.117 & $.000^{\mathrm{a}}$ \\
& Residual & 11.007 & 97 & .113 & & \\
& Total & 17.842 & 99 & & & \\
\hline
\end{tabular}

a. Predictors: (Constant), Kompensasi, Motivasi

b. Dependent Variable: Kinerja Karyawan

\begin{tabular}{lrrrr}
\hline Model & R & R Square & $\begin{array}{c}\text { Adjusted R } \\
\text { Square }\end{array}$ & $\begin{array}{l}\text { Std. Error of } \\
\text { the Estimate }\end{array}$ \\
\hline 1 & $.619^{\text {a }}$ & .383 & .370 & .33686 \\
\hline
\end{tabular}

a. Predictors: (Constant), Motivasi, Kompensasi

b. Dependent Variabel : Kinerja Karyawan 